\title{
Reasons Preventing Teachers from Acting within the Framework of Ethical Principles ${ }^{1}$
}

\author{
Nilgün Dağ \\ Nevsehir Hacı Bektas Veli Unversity, Faculty of Education, Primary Education \\ Department, Nevsehir, Turkiye, nilgundag@yahoo.com
}

\section{Halis Adnan Arslantaş}

Eskisehir Osmangazi University, Faculty of Education, Social Studies Education

Department, Eskisehir, Turkey, haarslantas@gmail.com

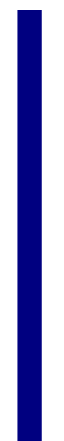

This study aims at putting forth the reasons preventing teachers from acting ethically, acting within the framework of ethical principles and having an ethical tendency. This study featuring a qualitative research model taking as a basis the case study approach followed a path of selecting people that can be a rich source of information for research instead of a random sampling to represent the universe. In this research where snowball sampling method is used datas have been obtained through negotiations with seven teachers on duty in Sinop city center. According to the results of the research, reasons preventing teachers from ethical behavior, acting within the framework of ethical principles were categorized under headings of "bureaucratic framework", "attitude of administrators", "corporate", "economic", "personal" and "occupational incompetence".

Key Words: ethic, ethical principles, primary education, professional ethic, teachers

\section{INTRODUCTION}

The studies in Turkey regarding ethics within the last twenty years demonstrate that ethical thinking and behavior are started to be considered as a necessity peculiar to the business world rather than a general activity involving all aspects of human life. As a matter of fact, the gradual increase in the number of the studies conducted in the field of occupational ethics and spreading of the congresses to this end verify the evaluation. Occupational ethics is a type of ethics regulating the behaviors of people engaged in a business. Every occupation has an ethical content and ethical principles set in line with that content. Every occupational person should achieve his/her occupational targets acting in line with those norms and principles in his/her actions and activities. It is

\footnotetext{
${ }^{1}$ This study was submitted as an oral presentation in the 22nd National Congress on Educational Sciences held in Eskisehir Osmangazi University on 5-7 September 2013.
}

DOI: $10.12973 / \mathrm{iji} .2015 .823 \mathrm{a}$ 
certain that there are some conditions and developments that hardens for or prevents one from acting in line with the ethical principles. It is quite possible that such factors deviating one from ethical path differ in occupational context. Surely, non-ethical attitudes have become widespread in all areas of today's world of private and social life where the balance between the physical and spiritual sides of man shook and attitudes and behaviors got indexed to the circumstances, which is a complex and significant case with its own psychological, sociological, cultural, corporate and situational reasons. However, this research focuses only on reasons preventing teachers from acting ethical, within the framework of ethical principles or taking an ethical trend rather than nonethical attitudes in all areas of social life in all kinds of collective relationships.

Teaching is a profession considered distinguished and sacred in Turkey. Besides its significance and value to the society, teaching is an occupation to be performed professionally. As a matter of fact, Article 43 of the Principle Code of National Education dated 14 June 1973 and numbered 1739 defines teaching as "a specialized occupation undertaking the education, training and related management tasks of the state". Since teaching requires working with children/youth who haven't yet gained the capacity to self-protection and defense, it is a special and significant task to be performed by virtuous occupational people who are specially elected and trained, knowledgeable, who also bear the values which the occupation requires (Özcan, 2011). Consequently, heeding and supervision of such ethical principles and norms in the occupational works and performance of a teacher is an obligation due to the nature of the occupation. Nevertheless, there might be cases aggravating and preventing working of a teacher within the framework of ethical principles. Dağ and Taşkaya (2012) notes that those reasons may be due to emergence of ethical principles in accordance with the atmosphere, circumstances and the addressee; that is, the teacher's transforming his/her attitudes per the atmosphere, circumstances and addressee instead of inherent management and supervision of his/her attitudes within the framework of ethical principles. Therefore, it would be useful to touch upon the ethics concept before diving into those reasons.

The word "ethics" is derived from the root "ethos" meaning disposition, character and personality in Latin. It is a set of principles on what a society or group deems right or wrong (Ryan ve Bisson, 2011). The meaning of ethical principles and values is rational thinking on their source, purpose and scope. More clearly, it is a branch of philosophy examining the character, base and essence of good or evil, right or wrong actions in terms of morals. According to Feldman (2012: 11), it is "examination of morals on philosophical plane".

In general terms, ethics is considered under two headings as "theoretical" and "practical". Corporate ethics emerging with Socrates and Plato is examined and analyzed under three headings as "normative (rule making)", "descriptive" and "metaethics (solving ethics)". Normative ethics is the "area of examination of the ethical standards, principles, concepts, values and theories" (Resnik, 2004: 35). In other words, it is a type of ethics stipulating what is good and right and what is bad and wrong for people, indicating what kind of life they should live and what principles to follow, and 
imposing regulatory and judgmental norms and principles to people for their acts and actions. Ethics is a branch dealing with what "should be" rather than what "is". Descriptive ethics tries to describe and define moral demands and norms instead of forming them, thus constituting a source and basis to normative ethics. Metaethics is the type of ethics analyzing/resolving the concepts and prepositions of the ethical domain; and therefore called the "logic of ethics", "science of ethics".

As to practical ethics, "it examines implementation of ethical dilemmas, choices, standards and ethical theories and concepts that might arise in various occupations and certain cases to a certain subject" (Fox ve DeMarco, 1990; Akt: Resnik, 2004: 35). Some of the problems discussed within the framework of practical ethics are the problem only of employees of a certain occupation, in contrast to some that concerns everyone. Those problems concerning everyone are aggregated under two categories: (1) Problems concerning the relations between people (abortion, religious and sexual discrimination, starvation, poverty, etc.) and (2) problems concerning the relations of people with other things (how to treat animals, plants, ecosystem and in general with the nature etc.) (Ünder, 2001: 341).

Occupational ethics, which is a type of practical ethics, refers to the whole of the guidelines, standards and principles directing one's attitudes and guiding him/herself in practice of his/her occupation (Şentürk, 2009). The purpose of occupational ethics is to put forth the principles and values to shape the moral, social and psychological features of the occupational members and to take them to what's better, right and ideal (Dağ ve Taşkaya, 2012). According to Kuchuradi (2009), occupational ethics is a specific and concrete field of practice of ethics because ethical problems consist of problems requiring the knowledge of the concerned branch of science to find out what needs to be done in a certain condition although they are no different problems from those people encounter performing their occupations.

The ethical principles of teaching as an occupational branch are "professionalism, commitment, justice and equality, neutrality/impartiality". Professionalism is a significant prerequisite that a teacher should gain about what kind of knowledge and skills he/she can pursue his/her service in his/her profession. The principle of commitment to work is a significant one in coordination with and supplementary to sense and responsibility of duty. Commitment to work can be interpreted as not only "psychological identification with work" but also "motivation to actively engage in the work". Being fair and equal is not only an ethical principle to be observed in all kinds of performances of the teacher, but also a significant guarantee that students will feel safe about they being treated fairly, equally and justly. As to neutrality/impartiality, it expresses the teacher being in an attitude embracing, joining, integrating and infusive all of the students without regard to differences such as language, religion, race, culture, gender, age, belief, political opinion, socio-economic condition etc; in brief, exhibiting an objective attitude to the differences of the students (Dağ ve Taşkaya, 2012).

Without doubt, there are some reasons and circumstances that may prevent them from action within the framework of, or detract them from commitment to, ethical principles. The investigation of Şakar (2010) puts forth that teachers do not possess the knowledge 
of the concept of ethics, that with the concept virtue, they express the features of a virtuous person rather than the knowledge the concept; that they have an awareness regarding being a model, but they are in a chaos on what the reference should be in acting as a model. Besides, it has been found out in this research that teachers use some concepts regarding the occupational ethics; however that they do not possess the knowledge of occupational ethic codes.

Toprakçı and colleagues (2010) have found out to what extent and why the teachers performing in primary schools abide by the ethical principles set forth in the "Regulation on Ethical Behavior Principles of Civil Servants and Principles and Procedures of Application" based on the opinions of teachers. As a result of the research, it was found out that teacher behaviors comply with "Public Occupational Ethic Principles" at "good (4)" level at a scale of 5. In addition, this research discovered that senior teachers comply to ethical principles more than the young teachers do, and that teachers considering the basis of ethics as "religion" comply with ethical principles less than those not

Uğurlu (2008) investigated perceptions of high school students on the ethical behaviors of their teachers. Accordingly, students made a positive evaluation of their teachers in subjects that can be associated with social and educational aspects of teaching professions, however a negative one about their attitudes in matters about them ("Our teachers are impartial in their relations with us", "Our teachers act just to us", "Our teachers have dedicated themselves to our bringing up", "Our teachers are affectionate to us").

Küçükkaraduman (2006) heard the opinions and evaluations of 280 teachers on whether the attitudes of principals in primary schools abide by ethical principles. According to the opinions of the teachers participating in the research, the ethical principle that is realized to the highest extent by school principals is "respect" in contrast to "tolerance", which they exhibit minimally.

Some researches (Jones ve Kavanagh, 1996; Keith, Pettijohn ve Burnett, 2003) on nonethical behaviors show that being influenced by or emulating others play a major role in making ethical decisions and behaving within the framework of ethics. As a matter of fact, Kohlberg (1969) highlights that one is influenced by the behaviors of, emulates, or takes as model others because he/she seeks social clues in distinguishing between proper and improper behaviors.

\section{METHOD}

\section{Research Model}

This study exhibits a pattern consisting of qualitative research model and takes as a basis the case study approach. Case study is an empirical research method which studies a current event within its real life framework (content), in which the borders between the phenomenon and surrounding content that involves the same are not absolutely obvious, and which is used when more than one proof or data source are available (Yin, 1984: 23; Akt: Yıldırım ve Şimşek, 2008: 277). In brief, case study is a research method based 
on "holistic analysis of one or more cases within their own circumstances (environment, time etc.) (Yıldırım ve Şimşek, 2008: 79). Although this method is thought as a means of conceptualizing or summarizing the social behaviors of people, its strategic significance lays in its capacity to attract attention to what can be learned from a single case (Schram, 2006: 107; Akt: Günel, 2013: 31).

The case in this research is the non-ethical behaviors of the classroom teachers. Researchers had direct interviews with classroom teachers; and tried to deduce from their opinions and experiences the factors that prevent them from acting within the framework of ethical principles and taking an ethical tendency. The data gained with the research is applicable for only participants subject to the case study, and limited to their personal opinions and experiences.

\section{Participants}

The study followed the path of selection of people that can become a rich source of information instead of a random sampling to represent the universe. This investigation applying the snowball sampling method has been realized with seven classroom teachers working in five primary schools in the city center of Sinop in 2012-2013 academic year. It was also noted if teachers accepted interview and are willing to participate.

All of the teachers are active in state schools and have an occupational experience of 10 years and above. The information on the gender, age and occupational seniority of the teachers is given in Table 1 .

Table 1: Descriptive Particularities of Participants regarding their Gender, Age and Occupational Seniority

\begin{tabular}{ccc}
\hline Participants & Age & Occupational Seniority \\
\hline $\mathrm{B}$ & 43 & 21 \\
\hline $\mathrm{M}$ & 35 & 14 \\
\hline$\dot{\mathrm{I}}$ & 40 & 17 \\
\hline $\mathrm{H}$ & 39 & 16 \\
\hline $\mathrm{Z}$ & 33 & 11 \\
\hline $\mathrm{G}$ & 40 & 19 \\
\hline $\mathrm{F}$ & 32 & 10
\end{tabular}

As you see in Table 1, the names of the participants included in the research have been coded with the letters B, M, İ, H, Z, G and F, and the interviews were made according to the sorting in the table. Five of the participants are female and two are male. While the occupational experience of three of the participants is between 10 to 15 years, three have between 15 to 20 years, and one over 20 years.

\section{Data Collection Process}

In case studies, usually more than one data collection methods are used to reach a data range to confirm each other. The data collection techniques used most frequently are interview, observation and document analysis. These methods can be used not only by themselves but also together (Yıldırım ve Şimşek, 2008). Data have been collected from 
the oral statements of the participants answering the research question and telling their experiences, and were evaluated also observing their attitudes and behaviors during the interview. In other words, the research has been conducted in two stages. In the first stage, approximately 25-minute interviews were held in a time period decided to be suitable both for the researcher and the participant in a proper location within the school. Afterwards, the participants were asked to talk about their experiences regarding non-ethical behaviors, and finally the behaviors of the participants recorded via a camera were analyzed.

As known, one of the data collection techniques commonly used in qualitative research is interviews. Interview is a quite handy technique to understand how people think and feel for cases that cannot be directly observed, and it is possible to get access to the experiences and future prospects of people through interviews (Darlington ve Scott, 2002). Another data collection technique commonly used is observation. Observation is a look and listening directed to certain targets to collect information pertaining to a certain person, place, incident, object, condition and circumstance (Karasar, 1995: 156); in brief, observation is the process of diagnosing people, incidents and circumstances.

The research has been conducted with seven classroom teachers working in five primary schools in the city center of Sinop in the spring semester of 2012-2013 academic year. Classroom teachers volunteering for interview have been visited in the schools they work and an appointment was made for the interview date and time. Interviews were realized in an available spot in the school they work (teachers' room, empty classrooms and school library) as of the date and time specified. The interviews were recorded using a tape recorder, and all of the teachers allowed recording of the interviews via a tape recorder. A conversational approach has been adopted in interviews, and the question "In your opinion, what are the reasons preventing teachers from acting in line with ethical principles" was asked to the classroom teachers in line with the purpose of the research, aiming them to share their experiences.

\section{Validity and Reliability}

The data acquired from interviews to increase the validity of the study has been reported in detail in the form of direct quotes. The teachers were given interview notes to increase the reliability of the study to confirm that the interview records are complete and free of mistakes. Besides, the path followed in each stage of the study was described in detail, and the analysis of the data was examined by two more researchers.

\section{Analysis of the Data}

Qualitative data acquired as a result of the interviews with the teachers were analyzed using descriptive analysis method. The answers of the teachers to the interview questions being transferred to computer environment, and having found out the common aspects of the answers at the first stage of the analysis, the categories under which they were to be arranged and presented have been determined. The answers by the teachers to the interview questions were conveyed as direct quotations in their own words and then tried to be interpreted. When quoting, letters were used instead of the names of the teachers. 


\section{FINDINGS}

Data acquired as a result of the interviews with the participants were analyzed via descriptive method. The answers of the participants were described systematically and expressly; and then those descriptions were interpreted to draw some conclusions. According to these conclusions, reasons preventing the teachers from ethical behavior, action in line with ethical principles or taking an ethical trend were categorized under headings of "bureaucratic structure", "attitudes of the administrators", "parent attitude and status" and "occupational incompetence".

\section{Findings regarding Reasons arising from Bureaucratic Structure}

Four of the teachers specified that some reasons arising from bureaucratic structure prevent them from acting ethically, action within the framework of ethical principles or taking an ethical trend. Some statements of the teachers indicating their opinions on the matter are given below.

"The major reason hardening ethical attitude in my opinion is the bureaucratic structure. As in shit rolls downhill. For example, the Ministry has RIDEF (Risk and Need Evaluation Form) forms it requires from teachers. Unfortunately no teacher, including myself, fill in those forms consciously. Because it is not possible for us to read and evaluate thousands of items one by one for each and every student. It takes hours of our time. And considering the teachers in village schools, there is no parent knowing how to use computers in their villages. It is another problem that the citizens in the village don't understand the forms. Because the parents don't understand, teachers fill in the forms required to be filled in by the parents too...". (Teacher B)

"There are several reasons for that. But behind all lies a systematic reason. Of which teachers are also a part. The service point taken as a basis in appointments is a systematical problem. While the service point of a teacher serving in the East is, say 120 , the service point of a teacher working in the West is 60. In other words, a teacher serving in the west earns the same service point as a teacher serving for a year in the east in 6 to 10 years. So the teacher has to find another way. Pulling some strings. . . . There is a practice called Ministerial Order. In the Ministerial order appointments, service point is not heeded. As the name implies: order of the minister. I have had some teacher friends forcing that path. It is not ethical perhaps, but one uses it when he has to.". (Teacher F)

"I think one of the biggest reasons precluding ethical behavior is competition and greed for benefit. Some people disregard any value when their benefits are in question. Unfortunately corporate process, so to speak, appreciates those people rather than externalizing such people. I think it even forces them to act this way. Because the system process unfortunately does not allow both ethical behavior and acting in accordance with benefits. A teacher earns nothing for acting different from the way of the majority, even ethical. On the contrary, he or she is marginalized.”. (Teacher H) 
"...In fact, the educational system is also to blame about that. System is currently in such a fashion that a student attending the school without studying at all can still graduate. The only expectation of both the system and teachers is that the student should cause no problems. If we, as teachers, are deviating from ethical principles, we should not ignore the share of the system in that". (Teacher M)

\section{Findings regarding Reasons arising from the Attitudes of the Administrators}

Two of the teachers expressed that administrative reasons harden/prevent acting within the framework of ethical principles. The expressions of those teachers are quoted below.

"There are reasons arising from Administrators, parents, and students, and in fact there are reasons arising from teachers too. If you ask whose share is the biggest, I'd say administrators. Because when the school administration doesn't take ethical decisions and act ethically, teachers will not behave ethically either. . . . Last year there was a classroom teacher in our school, who is practicing in another school now. That teacher put his 15-20 successful students to the trial test arranged by the Provincial Directorate of National Education, not all of the students in his classroom. So all of the students taking the exam had high points. Because students who were already successful took the exam. Mr. Principal awarded a certificate of success to that teacher. It is not supposed to happen, but it did. Those certificates are significant in becoming an administrator. Consequently, I started to do so, even if I don't approve. It is not ethical but it is the way administrative things go. It leaves no choice.”. (Teacher G)

“...This is something about the working environment. It is about the approaches of the administrators to non-ethical practices. If the principal and deputy principals try to create an ethical atmosphere, teachers do not, cannot deviate from ethical principles. They would know they are to be excluded when they do.”. (Teacher I)

\section{Findings regarding Reasons Caused by the Attitude and Status of Parents}

Four of the teachers specified that non-ethical behaviors result from the attitude and status of parents. The explanations of those teachers are quoted below.

“There isn't much in fact. But sometimes some parents can pass the line in parent meetings. They think they are employers and I am an employee. They use a tone like "questioning" against me. It is very hard for me to rid of the effect of that tone. Since I am a positive person, I don't want the children of such parents in my classroom. Aggressive and tense parents disturb me psychologically.”. (Teacher Z)

"The father of one of the students in my classroom holds me responsible for the failure of his son. He says I don't deserve the money. He defames me on every occasion. He acts without courtesy and he did that a few times beside my colleagues. So I requested from Mr. Principal to take the student to another classroom. Because I got unable to care about the child because of his father's attitude. However that was something wrong. Empathizing, I think I did something wrong”. (Teacher F) 
“...The parent has his contributions, doesn't he? Of course he does. I teach the daughter of an inspector of the province. She acts in a spoilt manner occasionally. But I tolerate, to tell the truth. Because his father is a good man, and an inspector, his daughter is a hardworking student. I should tolerate all students as much as I can, but we are a sentimental nation. So I might be coddling a little more for her.". (Teacher G)

"...Let's not forget the contribution of the parents. But I think this is an indirect contribution. The parents in fact react to the system change in the person of the teacher. Because the teacher is their closest addressee. Of course we are a nation inclined to look for a scapegoat for every business that goes wrong...". (Teacher İ)

\section{Findings regarding Reasons arising from Occupational Incompetence}

The statements of a teacher expressing that non-ethical behaviors arise from occupational incompetence are given below:

“...We blamed the system enough, so we could blame ourselves too. Teachers not respecting the teaching profession is as disturbing as the problems of the system to me. There are some teachers, believe me I doubt if they have a teaching diploma. They are so unknowledgeable and ignorant. The worst part of it is they are aware of that. I doubt if they learn facts about the psychological conditions and course success of students. To cover for that, they butter up the administrators, so to speak. . . . Those teachers doesn't inform the parents correctly about the true condition of the students. And because the parent is not concerned and unknowledgeable, students are left alone without any kind of care. Therefore I think those teachers should be rehabilitated. Unfortunately there are some colleagues I believe they should be ostracized from profession. Poor students. Poor our country.". (Teacher $\mathrm{M}$ )

\section{CONCLUSION}

Human being is a moral being due to his/her nature. He/she should act in view of such moral principles and norms in his/her daily life and occupational acts and actions. This research aims at revealing what the reasons causing non-ethical behavior are. There are two fundamental differences distinguishing between this research and others. The first is performance of the research with those actually performing the teaching profession rather than candidate teachers; and the other is the question asked to them being what the reasons causing non-ethical attitudes, rather than what they evaluate as non-ethical. In the light of this objective, face-to-face interviews were held with the seven classroom teachers participating in the research, and they were asked "In your opinion, what are the reasons preventing teachers from acting within the framework of ethical principles?" The common aspects of the answers of the teachers to the interview question being established, they were categorized under headings of "bureaucratic structure", "attitudes of the administrators", "parent attitude and status" and "occupational incompetence".

While four of the teachers indicated that non-ethical behaviors arise from the attitude and status of the parents, two of the teachers expressed that administrative reasons 
harden/prevent acting within the framework of ethical principles. While one teacher stated occupational incompetence caused non-ethical behaviors, four teachers indicated that the administrative work load caused by the bureaucratic structure leads to nonethical behaviors.

While a teacher highlighted that partiality in appointments caused string-pulling being used as a recipe of salvation, and another teacher expressed that encouragement by the system of competition instead of cooperation hardened/prevented an ethical trend. Furthermore, it is seen that some forms required to be filled in by the Ministry obliges teachers to conduct non-ethical practices.

In the research by Altınkurt and Yilmaz (2011), it was shown that the most frequent non-ethical behavior of the teachers is "failure to care adequately about students with a low success level". In this research, the case is - according to the statement of a teacher - due to parent attitudes.

In the research by Şişman and Acat (2003), it was found out that perception of new starting teachers regarding ethical values is more negative compared to the seniors. In other words, teachers experience more ethical dilemmas in the first years of their occupation, and perhaps conduct a higher number of non-ethical behaviors than seniors. In this research, most of the teachers participating in the research acknowledged conducting non-ethical behaviors despite they have substantial occupational experience. It should be kept in mind that non-ethical and unprincipled behaviors of teachers due either to bureaucratic structure or the attitudes and statuses of parents and administrators or occupational incompetence may cause adverse effects on several aspects ranging from corruption in occupational values and habits to a character flaw in the personality of the teacher, and to a deficiency in the thought and value world of the student, and the reasons causing non-ethical behaviors should be put forth with more comprehensive quantitative researches on bigger masses.

\section{REFERENCES}

Altınkurt, Y. \& Yılmaz, K. (2011). Öğretmen adaylarının öğretmenlerin mesleki etik dışı davranışlar ile ilgili görüşleri. Mehmet Akif Ersoy Üniversitesi Eğitim Fakültesi Dergisi, Y1l: 11, Say1: 22, s. 113-128.

Dağ, N. ve Taşkaya, S. M. (2012). Öğretmenliğin meslek etiği üzerine betimsel bir çalışma. Uluslar arası Türk Kültür Coğrafyasında Eğitim Bilimleri Araştırmaları Sетровуити, 1-3 Ekim, Sinop.

Darlington, Y. \& Scott, D. (2002). Qualitative research in practice: Stories from the field. Crows Nest, Sydney: Allen \& Unwin.

Feldman, F. (2012). Etik nedir? (Çev.: F. B. Aydar). İstanbul: Boğaziçi Üniversitesi Yayınları.

Günel, E. (2013). Nitel araştırmayla tanışma (s. 1-36). Nitel araştırmaya giriş. Çev. Edt.: A. Ersoy ve P. Yalçınoğlu, 2. Baskı, Ankara: Anı Yayıncılık. 
Jones, G. E. ve Kavanagh, M. J. (1996). An experimental examination of the effects of individual and situational factors on unethical behavioral intentions in the workplace. Journal of Bussiness, 15 (5), pp. 511-523.

Karasar, N. (1995). Bilimsel araştırma yöntemi. Ankara: Nobel Yayıncılık.

Keith, N. K., Pettijohn, C. E. ve Burnett, M. S. (2003). An empirical evaluation of the effect of peer and managerial ethical behaviors and the ethical predispoisitions of prospective advertising employees. Journal of Bussiness Ethics, 48 (3), pp. 251-265.

Kohlberg, L. (1969). Stage and sequence: The cognitive-developmental approach to socialization. In D. A. Goslin (Ed.), Handbook of Socialization Theory and Research (pp. 37-480), Chicago: Rand McNally.

Kuçuradi, I. (2009). Felsefi etik ve meslek etikleri. Etik ve Meslek Etikleri (Hz.: H. Tepe), 2. Baskı, Ankara: Türkiye Felsefe Kurumu Yayınları.

Küçükkaraduman, E. (2006). İlköğretim okul müdürlerinin etik davranışlarının incelenmesi (Ankara ili, Mamak ilçesi örneği). Gazi Üniversitesi Eğitim Bilimleri Enstitüsü Eğitim Yönetimi ve Denetimi Anabilim Dalı Yayınlanmamış Yüksek Lisans Tezi.

Özcan, M. (2011). Bilgi Çağında Öğretmen Eğitimi, Nitelikleri ve Gücü Bir Reform Önerisi. Ankara: TED Yayınları.

Resnik, D. B. (2004). Bilim etiği (Çev.: V. Mutlu). İstanbul: Ayrıntı Yayınları.

Ryan, T. G. ve Bisson, J. (2011). Can ethics be thought?. International Journal of Bussiness and Social Science, 2 (12), pp. 44-52.

Şakar, M. C. (2010). İlköğretim sınıf öğretmenlerinin etik görüşlerinin değerlendirilmesi. Yüzüncü Yıl Üniversitesi Sosyal Bilimler Enstitüsü Eğitim Bilimleri Anabilim Dalı, Yayınlanmamış Yüksek Lisans Tezi.

Şentürk, C. (2009). Öğretmenlik mesleğinde etik. Bilim ve Aklın Aydınlı̆̆ında Ĕgitim, Y1l: 10, Sayı: 111, s. 25-29.

Şişman, M. ve Acat, B. (2003). Öğretmenlik uygulaması çalışmalarının öğretmenlik mesleğinin algılanmasındaki etkisi. Fırat Üniversitesi Sosyal Bilimler Dergisi, 13 (1), s. 235-250.

Toprak, E., Bozpolat, E. ve Buldur, S. (2010). Öğretmen davranışlarının kamu meslek etiği ilkelerine uygunluğu. E-International Journal of Educational Research, Cilt: 1, Say1: 2, pp. 35-50.

Uğurlu, C. T. (2008). Lise son sınıf öğrencilerinin öğretmenlerinin etik davranışlarına ilişkin algıları. Kastamonu Ĕgitim Dergisi, Cilt: 16, No: 2, s. 367-378.

Ünder, H. (2001). Uygulamalı etik: Panmoralizm. 1. Ulusal Uygulamalı Etik Kongresi, 12-13 Kasım, Ankara, s.341-345.

Yıldırım, A. ve Şimşek, H. (2008). Sosyal bilimlerde nitel araştırma yöntemleri. 6. Baskı, Ankara: Seçkin Yayınları. 


\section{Turkish Abstract}

\section{Öğretmenleri Etik İlkeler Çerçevesinde Hareket Etmekten Alıkoyan Nedenler}

Bu çalışma, ögretmenleri etik davranmaktan, etik ilkeler çerçevesinde hareket etmekten ve etik bir yönelime girmekten alı koyan nedenleri ortaya koymayı amaçlamaktadır. Nitel araştırma modelinden oluşan bir yapı sergileyen ve durum çalışması yaklaşımını esas alan bu çalışmada, evreni temsil edecek rastgele bir örneklem yerine araştırma için zengin bilgi kaynağ kişilerin seçilmesi yolu izlenmiştir. Kartopu örnekleme yönteminin kullanıldığ 1 araştırmada veriler, 2012-2013 eğitim-öğretim yılının bahar yarıyılında Sinop il merkezinde görev yapmakta olan yedi öğretmen ile yapılan görüşmeler yoluyla elde edilmiştir. Araştırma sonuçlarına göre öğretmenlerin etik davranmalarını, etik ilkeler çerçevesinde hareket etmelerini veya etik bir yönelime girmelerini engelleyen nedenler "bürokratik yapı", "idarecilerin tutumları", "velinin tutumu ve statüsü” ve "meslekî yetersizlik" başlıklar altında kategorileştirilmiştir.

Anahtar Kelimeler: etik, etik ilkeler, ilköğretim, profesyonel etik, öğretmenler

\section{French Abstract}

\section{Raisons Empêchant Professeurs d'Agir dans le cadre de Principes Éthiques}

Cette étude vise à avancer les raisons empêchant des professeurs d'agir éthiquement, agissant dans le cadre des principes éthiques et ayant une tendance éthique. Cette étude représentant un modèle de recherche qualitatif prenant comme une base l'approche d'étude de cas a suivi un chemin de choisir les gens qui peuvent être une source riche d'informations pour la recherche au lieu d'un échantillonnage aléatoire pour représenter l'univers. Dans cette recherche où la boule de neige échantillonnant la méthode est utilisée a été obtenue par des négociations avec sept professeurs de service dans le centre-ville Sinop. Selon les résultats de la recherche, les raisons empêchant des professeurs du comportement éthique, agissant dans le cadre des principes éthiques ont été catégorisées dans les titres "du cadre bureaucratique", "l'attitude d'administrateurs", "d'entreprise", "économique", "personnel" et "l'incompétence professionnelle".

Mots Clés: éthique, professionnel éthique, fait d'être instructif, professeur, cadre

\section{Arabic Abstract}

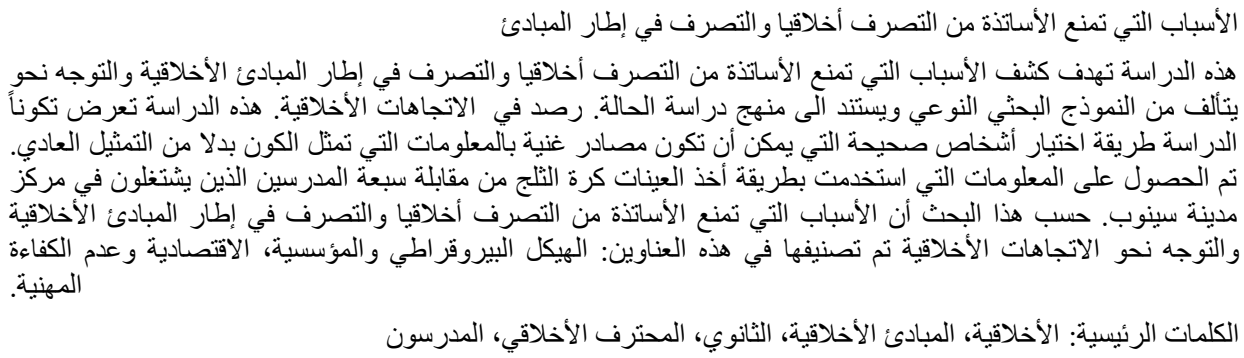

